\title{
What's in a Word? Just vs. Fair vs. Appropriate Earnings for Self and Others
}

\author{
Jule Adriaans $^{1}$ (D) $\cdot$ Stefan Liebig ${ }^{1}$ (D) $\cdot$ Clara Sabbagh $^{2}$ (D) $\cdot$ Guillermina Jasso $^{3}$ (D)
}

Accepted: 20 September 2021 / Published online: 8 October 2021

(c) The Author(s) 2021

\begin{abstract}
Despite Rawls' famous call to distinguish between justice and fairness, these and other justice-related words often seem to be used interchangeably by both ordinary people and justice researchers. Based on a survey-embedded question wording experiment $(N=4534)$ fielded in Germany as part of the GESIS Panel, we explore the effects of three justice words — "just," "fair," and "appropriate"—on the sense of justice about earnings for self and others. We observe differences in the just reward, justice evaluation, and justice consequences by justice word. For example, justice evaluations of one's own earnings are more negative, i.e., deeper in the underreward territory, signaling larger just rewards, when using "just" instead of "fair" or "appropriate" in the question wording. No such clear pattern emerges for justice evaluations of others' earnings. Our analyses show the decreasing effect of an underreward situation on psychosocial health to be significantly stronger in the "just" condition compared to the "fair" condition but do not reveal differential consequences by justice word for measures of satisfaction and trust. Overall, the observed differences by justice words are moderate in size. Nonetheless, our findings suggest caution for justice researchers in communicating with peers and respondents and warrant further inquiry extending research on the role of "justice language" to other language-country contexts.
\end{abstract}

Keywords Justice words · Justice of earnings · Question wording · Surveyembedded experiment · German-Germany

\section{Introduction}

More than 60 years ago, Rawls (1958, p.164) forged a new frontier in the study of justice with the celebrated opening lines:

Jule Adriaans

jadriaans@diw.de

Extended author information available on the last page of the article 
It might seem at first sight that the concepts of justice and fairness are the same, and that there is no reason to distinguish them, or to say that one is more fundamental than the other. I think that this impression is mistaken [...].

Since then, philosophers and social scientists have sought to understand the exact meaning of the two words "justice" and "fairness" and their exact difference, relying, as Rawls $(1958,1971)$ did, and in concert with empirical social science, on the "ordinary speech" of ordinary people (e.g., Rawls, 1958, pp. 179-180). Notwithstanding ubiquitous attempts to distinguish between the two concepts; to establish how something can be "just" but "unfair" or "fair" but "unjust"; to introduce deities, governments, and laws to assist in making the distinction; to draw precise links to legitimacy, appropriateness, morality, impartiality, equity-and sometimes even with a flavor of "oughtness"- the ordinary speech of ordinary people remains the final arbiter. ${ }^{1}$

The ordinary speech of ordinary people struck an early blow, and it was not on the side of a distinction between justice and fairness. For, while English possesses both words (with "fairness" acquiring the justice meaning in Middle English, roughly 1150-1470), as does German (with "fairness" entering the language in the nineteenth century), most languages do not have distinct words for justice and fairness. ${ }^{2}$ As Sen (2009, pp. 72-73) notes, the French translation of Rawls' (1971) book writes of "la justice comme équité." Concomitantly, the Spanish translation renders it "la justicia como imparcialidad." Both raise the new challenge of establishing the relation between the French "justice" and "équité" and between the Spanish "justicia" and "imparcialidad" and their relation to the Rawlsian English-language concepts of "justice" and "fairness."

Meanwhile, researchers study what ordinary people think-i.e., public opinionon matters of justice by means of laboratory experiments, large-scale single country studies, as well as cross-country survey programs. In doing so, empirical work on the sense of justice has relied on the fundamental principle owed to Elaine Hatfield (Walster, Berscheid, \& Walster, 1973, p. 152) and Milton Friedman (1977), "Justice is in the eye of the beholder."3 But despite their explicit interest in understanding the conceptual differences, researchers seem to use "justice" and "fairness" interchangeably in their empirical endeavors to assess public opinion on matters of justice.

\footnotetext{
1 For exemplars of these lines of inquiry, see Colquitt and Rodell (2015); Cugueró-Escofet and Rosanas (2013); Fortin and Fellenz (2008); Goldman and Cropanzano (2015); Jasso, Shelly, and Webster (2019); Liebig (2001); Raphael (2001); Sabbagh and Schmitt (2016); and comments posted on the StackExchange on English Language and Usage (https://english.stackexchange.com/questions/100576/whats-thedifference-between-just-and-fair).

2 Sen (2009, pp. 72-73) writes that when he took to Rawls the objection raised, in conversation, by Isaiah Berlin that "'Justice as fairness'... can hardly be such a fundamental idea since some of the major languages in the world do not even have clearly distinguished terms for the two..., Rawls replied that the actual existence of sufficiently distinguished specialized words is really of little significance; the major issue is whether people speaking in a language that lacks a distinction based on a single word can nevertheless differentiate between the separate concepts, and go on to articulate the contrast using as many words as they need."

${ }^{3}$ Hatfield wrote "Equity is in the eye of the beholder," and Friedman wrote "Fairness is strictly in the eye of the beholder."
} 
Moreover, empirical justice research also sometimes uses other justice words, such as "appropriate." For example, the European Social Survey (ESS) uses all three justice words "just," "fair," and "appropriate," the International Social Survey Program (ISSP) uses both "just" and "fair," and the International Social Justice Project (ISJP) uses both "just" and "appropriate" in asking for justice evaluations. This usage occurs both in what researchers say to their study participants and in what they write in published papers. In their review of organizational justice measures Colquitt and Shaw (2005) explicitly point to the use of synonyms (namely "just" as a synonym of "fair") as a way to create repetition in justice scales (e.g., Earley \& Lind, 1987). However, if Rawls was right in assuming that ordinary people differentiate between justice and fairness, then empirical studies have been presenting to respondents a heterogeneous mix of justice stimuli.

In light of a rich tradition of research papers showing that seemingly synonymous changes to question wording are associated with substantial differences in response behavior (Huber \& Paris, 2013; Rasinski, 1989; Schuman \& Presser, 1981; Singer \& Couper, 2014; Smith, 1987), it is essential to understand the possibly differential effects of justice words if we are to understand the results obtained in empirical justice research. The question of differences in response behavior by justice word, therefore, has both theoretical and empirical implications, such as determining the reliability and validity of instruments measuring the sense of justice (e.g., Liebig, 2001). Thus, our study aims at exploring whether different justice words shape attitudinal responses in an adult population. We rely on a survey-embedded question wording experiment in a probability sample of German respondents.

Despite an expressed interest to distinguish "justice" and "fairness" in empirical justice research (e.g., Fortin \& Fellenz, 2008; Goldman \& Cropranzano, 2015), to our knowledge, the present paper marks the first systematic attempt to empirically assess to what extent and how three justice-related words-namely "just," "fair," and "appropriate"- shape the sense of justice about earnings for self and others. Thus, we extend existing empirical justice research concerning the question, "What do people think is just?" (Hegtvedt, 2006, p. 46; Jasso, 1978, p.1400) to the question, "Is there a difference between what people think is just and what people think is fair and what people think is appropriate?".

The paper is organized as follows. Section 2 introduces the theoretical framework and describes the study of the justice of earnings for self and others. Section 3 presents the etymology and usage in German of the three experimental justice words providing insights into differences in meaning among lay people. In Sect. 4, we describe the sample, data, and analytical strategy. Section 5 reports the results. Finally, we discuss implications of this work for further research on justice words across additional languages and countries.

\section{Distributive Justice}

Justice research spans a variety of domains, including distributive, retributive, procedural, interactional, and informational justice (Hegtvedt, 2006; Sabbagh \& Schmitt, 2016), and the practice of using justice words interchangeably extends across all of 
them. This paper focuses on distributive justice, more specifically on the justice of one's own and others' earnings.

Distributive justice refers, first, to individuals' ideas about the just amounts of valued resources, such as earnings, and the relative importance assigned to different justice principles used to guide and regulate their allocation (Deutsch, 1975; Hülle et al., 2018; Törnblom \& Kazemi, 2015). At least three major principles of justice have been proposed: equality, by which recipients should receive equal earnings; need, by which recipients with greater needs should receive higher earnings; and equity, by which recipients should receive higher earnings, the greater their effort, contribution, or productivity. Second, distributive justice refers to the subjective sense of (in)justice that is awakened when actual rewards are compared to subjective ideas of just rewards (Jasso, 1978). When actual earnings match just earnings, the situation evokes a sense of perfect justice. If actual earnings are lower than just earnings, this evokes a sense of deprivation (i.e., underreward); when actual earnings exceed just earnings, this evokes a sense of overreward. This basic understanding of distributive justice, called the justice evaluation process, triggers a long train of attitudinal and behavioral consequences (such as signing a petition and joining a protest).

The assessment that a given actual reward is just or unjust, and, if unjust, whether the injustice is of the underreward or overreward type, is called the justice evaluation, with zero representing the point of perfect justice, negative numbers representing unjust underreward, and positive numbers representing unjust overreward. Moreover, because there may be differences between what people think and what they say, the justice evaluation process distinguishes between the experienced justice evaluation, denoted $J^{*}$, and the expressed justice evaluation, denoted $J$. These ideas are formalized in the following equations (Jasso, 1978; Jasso \& Wegener, 1997):

$$
J^{*}=[\operatorname{sgn}(\theta)] \ln \left(\frac{A}{C}\right)
$$

and

$$
J=\theta \ln \left(\frac{A}{C}\right)
$$

where $A$ denotes the actual reward, $C$ denotes the just reward, and $\theta$ denotes the signature constant whose absolute value indicates the observer's expressiveness, now incorporated in the expressed justice evaluation (Jasso \& Wegener, 1997). ${ }^{4}$ When the actual reward (e.g., the amount of earnings received) equals the just reward (i.e., the amount of earnings considered just), $J^{*}$ and $J$ equal 0 , the point of perfect justice; when the actual reward is less than the just reward, the justice evaluation is a negative number, representing underreward; and when the actual reward is greater

\footnotetext{
4 The sign of the signature constant indicates the framing of the reward, i.e., whether the observer regards the reward that is distributed as a good or as a bad. For the applied case, we study in this paperthe justice of earnings — we assume that "earnings" are regarded as a good (i.e., a desirable resource to obtain) by respondents.
} 
than the just reward, the justice evaluation is a positive number, representing unjust overreward.

As the actual earnings increase, the justice evaluation increases, moving rightward, for example, from great underreward to less underreward to perfect justice to slight overreward to great overreward. As the just earnings increase, the justice evaluation decreases, moving leftward, for example, from great overreward to slight overreward to perfect justice to slight underreward to great underreward. Thus, as will be encountered below, justice evaluations moving leftward deeper into underreward territory imply larger amounts of just earnings, and conversely.

The log function further incorporates the idea that deficiency is felt more keenly than comparable excess (now called loss aversion). Finally, the equations can be used to assess the justice or injustice of both rewards received by self and by others (Jasso, 1978).

The justice evaluation process is accompanied by three other processes identified in justice theory: It is preceded by both the actual reward process and the just reward process and followed by the justice consequences process (Hegtvedt et al., 2016; Jasso et al., 2016; Liebig \& Sauer, 2016). (1) In the actual reward process, the allocator, guided by allocation rules, uses rewardee characteristics and other inputs to generate the actual reward $(A)$ for the rewardee. (2) In the just reward process, the observer, guided by justice principles, uses rewardee characteristics and other inputs to generate the just reward $(C)$ for the rewardee. These justice principles are thought to be of two kinds: (i) principles of microjustice, pertaining to the "why" in "who should get what and why"; and (ii) principles of macrojustice, pertaining to what the entire distribution of just rewards should look like (Brickman et al., 1981). To illustrate, microprinciples of justice refer to characteristics of a rewardee that are thought to warrant a higher (or lower) just reward. Borrowing from classic wage equations (Mincer, 1974), scholars of justice estimate the just returns to reward-relevant characteristics by regressing the just earnings on rewardee's age, education, and gender (e.g., Jasso \& Wegener, 1999; Sauer et al., 2016). Principles of macrojustice, on the other hand, keep the entire distribution in mind and are studied by investigating the resulting distribution of just rewards, for example, its mean or level of inequality (e.g., Jasso, 2007; Jasso \& Meyerson Milgrom, 2008).

As shown above, (3) the justice evaluation process then combines the actual reward formed in the actual reward process and the just reward formed in the just reward process to generate the justice evaluation. It is then followed by (4) the justice consequences process, in which the justice evaluation triggers a long train of justice consequences, possibly incorporating non-justice factors-stretching out to all areas of human behavior and the social life. Figure 1 provides visualization of the four processes in the world of distributive justice.

Of the four processes, the second through the fourth are specifically central to the study of justice and thus form the focus of this paper. If we are to understand how justice words affect the empirical study of distributive justice, we are tasked with understanding how they affect the entire range of justice operations. We, therefore, build on the comprehensive framework introduced above and study the wide panoply of justice operations: We explore the effects of the experimentally manipulated focal justice words on the micro- and macroprinciples of justice guiding the 


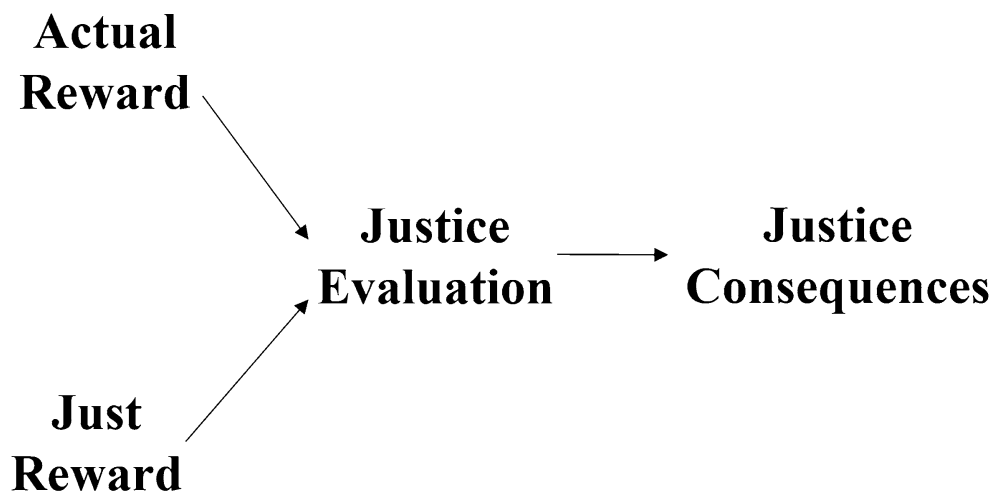

Fig. 1 The World of Distributive Justice. Source: Jasso et al. (2016, p. 202)

just reward process, on the expressed justice evaluation for self and others and the experienced justice evaluation for self, and on the justice consequences process, providing a comprehensive assessment of the role of justice words on the distributive justice of earnings.

\section{Justice Words in the German-Language Context}

As summarized in the Introduction, a variety of justice words are used interchangeably in empirical research studying the quantities of justice introduced in Sect. 2. Relying on the ordinary speech of ordinary people in understanding if what is considered "just" differs from what is considered "fair" or "appropriate," is further complicated because these justice words may have connotations that differ across language settings. For example, within a single language, meanings may differ across countries and cultures. Accordingly, in this first empirical foray we restrict attention not only to German but also to Germany, leaving for future work parallel studies in other German-speaking populations (e.g., in countries where German is an official language, such as Austria or Switzerland). In Germany, the most frequently used justice words in empirical research are "just" (gerecht), "fair" (fair), and "appropriate" (angemessen). ${ }^{5}$

Assuming that potential differences in the justice, fairness, and appropriateness of earnings can be traced back to differences in the meaning ordinary people attach to these words and in keeping with the call to study the ordinary speech of ordinary people, we refer to German dictionaries for insights into their contemporary meaning and etymology. We relied on three main sources-Duden (2018); Kempcke (2000); Seebold (2002) — to highlight potential differences in how the justice

\footnotetext{
${ }^{5}$ For the remainder of the article, the English versions of the words will be used. However, it is important to keep in mind that gerecht, fair, and angemessen are direct translations of the English words "just", "fair", and "appropriate", respectively, and identical meaning and connotations across languages cannot be assumed.
} 
words "just," "fair," and "appropriate" may affect respondents' justice assessments of earnings.

With roots in the Latin directus, the contemporary meaning of "just" appears by Gothic times ${ }^{6}$ and is "to act or judge in accordance with the sense of justice," "to judge someone or something appropriately" (Kempcke, 2000, p. 400), and "to be in accordance with the law" (Duden, 2018, p. 445). The word "fair" only entered the German language from English in the nineteenth century; its contemporary meaning is associated with behavioral components of justice as it implies the idea of being "decent, fair in his/her behavior towards others" (Duden, 2018, p. 362). "Fair" also has a close relation to the domain of sports relating to the expression of "fair play" adapted from English (Seebold, 2002). The word "appropriate" developed from the German word messen (English: "to measure"), and its contemporary meaning signals "according to the circumstances" (Duden, 2018, p. 89). Summarizing potential differences in contemporary German usage of these three justice words, "just," with its close association with the field of law, pertains to a formal sense of justice and provides a strong moral connotation. "Fair" also implies a moral judgment, but in the German language seems to refer to less formal and more situational ideas of justice (e.g., treating someone fairly, "fair play"), while, among the three justice words studied, "appropriate" suggests conventional behavior and a rather weak association with a moral standard (Turiel, 1983).

Accordingly, based on the etymology and meaning in contemporary German we would expect to find the standard of "earnings justice" to be particularly hard to reach, compared to the more informal "earnings fairness" and less morally charged "appropriateness of earnings," suggesting more negative evaluations of earnings, in the "just" condition compared to the "fair" and "appropriate" condition for our sample of German adults.

\section{Methods}

\section{Data and Experimental Design}

The role of different justice words in the empirical study of ideas of justice and assessments of injustice has not, to the best of our knowledge, been analyzed systematically. In order to isolate the effect of question wording on response behavior, we experimentally varied the justice words— "just" versus "fair" versus "appropriate"-for the same set of justice questions in an otherwise controlled setting as part of a general population panel study. Respondents were randomly assigned to one of three experimental groups. All three groups received identical questions on just earnings and justice evaluations of earnings for self and others. Totally, 1519

\footnotetext{
6 The Gothic language was a Germanic language used by the Goths, approximately from the third to the sixth century (Wolfram, 1990).
} 
respondents were randomly assigned to the "just" condition, 1522 respondents to the "fair" condition, and 1493 respondents to the "appropriate" condition.

The experiment was part of the GESIS Panel which is a probability-based mixed-mode panel that started in 2014 and runs its waves bimonthly using online computer-assisted Web interviews (CAWI) and offline paper-and-pencil interviews (PAPI). Respondents chose their preferred mode of participation. A majority of 67.1 percent participated in CAWI mode, while 32.9 percent of respondents participated in PAPI mode. The GESIS Panel provides a probability sample of the adult population living in Germany (Bosnjak et al., 2017), thus offering the ideal setting for a rigorous test of the effect of question wording on justice assessments. ${ }^{8}$ The question wording experiment was fielded in the 22nd wave of the GESIS Panel between February and April 2017. The analyses further draw on sociodemographic information collected in earlier waves as well as information on satisfaction, health, and trust collected in the next wave, the 23rd wave of the GESIS Panel fielded between April and June $2017 .^{9}$

\section{Analytical Strategy}

Question wording experiments are an important tool in understanding the role of specific words in public opinion research (Huber \& Paris, 2013; Schuman \& Presser, 1981). Including measures of all the justice terms and operations introduced in Sect. 2 allows for a rigorous investigation into the role of justice words in the study of distributive justice. Our general strategy is to test for the effect of justice words by contrasting across the three experimental groups all the estimates central to the study of the justice of earnings, from the just reward and the principles of justice to the expressed and experienced justice evaluations for self and the expressed justice evaluation for others to the justice consequences.

To illustrate, for the case of the just reward and principles of justice, we explore how ideas of the just reward differ across the three justice words and whether the

\footnotetext{
7 Effective randomization is crucial to the success of the experimental design. Comparing experimental groups on basic socio-demographics and variables studied in the upcoming analyses, we find the randomization to have been successful. There are no significant differences in the composition of experimental groups regarding age $(F=.42, p=.66)$, gender $(F=1.69, p=.17)$, education $(F=.02, p=.98)$, employment status $(F=.20, p=.82)$, life satisfaction $(F=1.04, p=.36)$, job satisfaction $(F=1.25$, $p=.29)$, satisfaction with democracy $(F=.10, p=.90)$, health satisfaction $(F=1.03, p=.36)$, psychosocial health index $(F=.92, p=.40)$, and generalized trust $(F=.60, p=.55)$.

8 The GESIS Panel sample consists of two separate starting cohorts. The initial starting cohort was sampled in 2013 followed by a refreshment sample in 2016 drawn from the ALLBUS survey. With bimonthly waves, respondents from both cohorts are experienced survey respondents. Testing for differences in response behavior between respondents from the two sampling cohorts did not reveal any systematic variation. Note that GESIS panelists had not been asked justice questions prior to fielding of the justice words experiment.

9 The analyses draw on the extended edition of the GESIS Panel data (GESIS (2021) Version 29.0; https://doi.org/10.4232/1.13244). The extended edition of the GESIS Panel data is available in the Secure Data Center at the GESIS Data Archive for Social Sciences in Cologne. In order to gain access to the data, researchers are required to sign a special data usage contract and to work in an individually setup, secure, virtual work environment at GESIS in Cologne.
} 
Table 1 Summary of Basic Justice Quantities

Type of earnings Type of information

\begin{tabular}{|c|c|c|}
\hline Expressed justice evaluation of one's own earnings ( $J$ ) & Grose and net & 11-noint scale \\
\hline Actual earnings $(A)$ & Gross and net & Open-format question, in $€$ \\
\hline Just earnings $(C)$-hybrid measure & Gross and net & $\begin{array}{l}\text { if } J=0, C=A \text {, otherwise: } \\
\text { Open-format question, in } €\end{array}$ \\
\hline $\begin{array}{l}\text { Experienced justice evaluation of one's own earnings }\left(J^{*}\right) \\
\text { Justice for others (nonreflexive justice variables) }\end{array}$ & Gross and net & $J^{*}=\ln (A / C)$ \\
\hline Expressed justice evaluation $J$ of top earnings & Gross & 11-point scale \\
\hline Expressed justice evaluation $J$ of middle earnings & Gross & 11-point scale \\
\hline Expressed justice evaluation $J$ of bottom earnings & Gross & 11-point scale \\
\hline
\end{tabular}

micro- and macroprinciples of justice used in the "just" reward process differ from the justice principles used in the "fair" reward process and the "appropriate" reward process. For the justice evaluations, we investigate whether expressed and experienced justice evaluations of one's own earnings and expressed justice evaluations of others' earnings are indeed more negative in the "just" condition compared to the "fair" and "appropriate" conditions, signaling larger just rewards. With regard to the justice consequences process, we test whether "justice," "fairness," and "appropriateness" of earnings are associated with the same consequences and if these associations are comparable in size.

\section{Variables}

\section{Justice Evaluation of Earnings}

Respondents were asked to evaluate the justice of their own net and gross earnings and the gross earnings of others. We study the justice evaluations of both gross and net earnings as these evaluations tap different elements of the justice of earnings. While evaluations of gross earnings refer to whether the employer's payment for work is "just," "fair," "appropriate," evaluations of net earnings also pertain to governmental intervention via income tax and social security contributions. The German questionnaire items and English translations are provided in the Appendix (see Tables 8 and 9). Variables for self were obtained only from respondents who received earnings from work, while justice for others was evaluated by all respondents of the GESIS Panel. Table 1 summarizes the basic justice quantities in which we test for the effect of question wording.

To illustrate for one's own net earnings, respondents were asked to evaluate their monthly earnings using an 11-point scale that ranged from -5 "[unjustly] [unfairly] [inappropriately] too low" through 0 "[just] [fair] [appropriate]" to +5 "[unjustly] [unfairly] [inappropriately] too high" (see Appendix Fig. 6).

Continuing the illustration, respondents who indicated they were "unjustly"/"unfa irly"/"inappropriately" paid were asked to state the monthly net earnings they would 
consider "just"/"fair"/"appropriate." Respondents were then asked to state their actual monthly net earnings. ${ }^{10}$

To calculate the experienced justice $J^{*}$, as per Eq. (1) in Sect. 2, we take the natural logarithm of the ratio of the actual earnings $A$ to the just earnings $C$. Just earnings $C$ is a hybrid measure constructed from information on actual net earnings, if the expressed justice evaluation indicates perfect justice (as in this case the just earnings equal the actual earnings), and from the direct question on just earnings otherwise. Identical questions on gross earnings were administered to all respondents receiving earnings from work.

All respondents of the GESIS Panel, regardless of their employment situation, were asked to rate the justice of gross earnings at the top, middle, and bottom of the earnings distribution using the same 11-point scale used for the assessments of one's own earnings. The three questions were accompanied by context information on typical occupations in the tenth, fifth, and first deciles of the earnings distribution in Germany, representing top, middle, and bottom earnings, respectively. (See Appendix Table 8 for exact question wording.) Simultaneous measurement of justice evaluations of earnings for both self and others allows us to explore whether the effect of justice words differs between reflexive and nonreflexive justice evaluations, both of which are central to the study of distributive justice (Jasso et al., 2016).

\section{Justice Consequences}

To assess justice consequences and test for differences by justice word, we focus on three important generalized consequences-self-reported satisfaction, health, and trust. Besides providing insights into the role of justice words in the justice consequences process, this allows us to assess concurrent validity (Lundmark, Gilljam, $\&$ Dahlberg, 2016). If the consequences of inappropriate underreward are different from the consequences of unjust or unfair underreward, this suggests differences in the underlying construct. Building on the notion that all of the three words experimentally varied are "justice words," we assume that all of them will show the expected correlations with self-reported satisfaction, health, and trust. Considering differences in meaning summarized in Sect. 3, we, however, explore whether the strength of association differs between experimental groups.

We include measures of life satisfaction and job satisfaction, as well as a measure of satisfaction with the way democracy works in Germany, and a measure of satisfaction with overall health. ${ }^{11}$ The four measures of satisfaction use an 11-point scale

\footnotetext{
${ }^{10}$ Respondents answered in an open answer format without plausibility checks. This resulted in a number of extreme outliers (e.g., additional zeros were added in stating the actual or just gross and net earnings). Earnings values (both actual and just earnings) were defined as extreme outliers when they differed by more than three standard deviations from the mean. According to this definition, 24 values were defined as extreme outliers and treated as missing.

11 Exact question wordings were: "How satisfied are you at the moment, all things considered, with your life?", "How satisfied are you with your work?", "On the whole, how satisfied are you with the way democracy works in Germany?", "How satisfied are you with your health?" to measure life satisfaction, job satisfaction, satisfaction with the way democracy works, and health satisfaction, respectively.
} 
that ranges from 0 "Not at all satisfied" to 10 "Completely satisfied." To complement the subjective assessment of health satisfaction, we calculated a psychosocial health index. ${ }^{12}$ Finally, we examined a measure of generalized trust. ${ }^{13}$ All measures that are investigated as consequences of experienced injustice were administered in the 23rd wave of the GESIS Panel.

\section{Other Variables}

To estimate the principles of microjustice, we specify just earnings equations in which the dependent variable is the natural logarithm of just earnings. The explanatory variables are the classic earnings-relevant worker characteristics (e.g., Adams, 1963; Mincer, 1974): respondent age, age-squared, and schooling-including dummy indicators for the highest degree obtained, viz. lower secondary (Hauptschule), intermediate (Mittlere Reife), upper secondary (Fachhochschulreife, Abitur), lower tertiary (Fachhochschule), and upper tertiary education (Hochschulabschluss). Finally, we include gender, whose operation in just earnings determination has been amply documented (Auspurg et al., 2017; Ridgeway, 1991; Valet, 2018).

To estimate the principles of macrojustice, we use two measures of location (mean and median) for the just reward and five measures of inequality in the distribution of just rewards (Atkinson, Gini, Theil Index, Theil MLD, CV). ${ }^{14}$

In the analyses of justice consequences, we also control for logged personal monthly gross earnings, as the level of personal income has been shown to affect measures of satisfaction, health, and trust and is thought to do so independently of the justice evaluation (e.g., Alesina \& La Ferrera, 2002; Sauer \& Valet, 2013; Schunck et al., 2015). Summary statistics for all variables are displayed in the Appendix (Table 10).

\section{Results}

This section reports the results of the justice words experiment. We examine the effect of the three justice words_- "just" versus "fair" versus "appropriate"—on basic justice quantities, starting with the just reward process, continuing with the justice evaluation process, and ending with the justice consequences process.

\footnotetext{
12 The psychosocial health index includes information from four questions asking respondents how often in the past four weeks they have "felt hounded or put under time pressure," "felt lots of energy" (reversely coded), "had strong physical pain," and "were constrained by physical or psychological problems in your social contacts, for example with friends, acquaintances, or relatives." All four items used the same 11-point scale ranging from "Never (0)" to "Always (10)." The resulting mean index of psychosocial health is reverse-coded and ranges from 0 (indicating poor psychosocial health) to 10 (indicating good psychosocial health) and captures dimensions of physical and mental health (Weinhardt \& Richter, 2014).

13 "Generally speaking, would you say that most people can be trusted, or that you can't be too careful in dealing with people?" with an 11-point scale ranging from "One can never be careful enough (0)" to "Most people can be trusted (10)."

14 Formulas and computational routines for the five inequality measures are provided in Jasso (2018).
} 


\section{Just Reward Process}

\section{The Just Earnings Function and the Principles of Microjustice}

As discussed in Sect. 2, the observer, guided by the principles of microjustice, forms ideas of the just reward for the rewardee. In this study, respondents form ideas of just earnings for themselves. To learn about the principles of microjustice guiding respondents, we estimate just earnings functions based on classic earnings functions (Mincer, 1974). To assess the effects of the three justice words, the natural log of the hybrid measures of the just, fair, and appropriate gross earnings is regressed on age and age-squared, gender, and the binary variables representing schooling attainment discussed earlier. The coefficients can then be read as the "just," "fair," and "appropriate" returns to each worker characteristic. We first estimate a separate model for each experimental condition and next estimate a joint model using a seemingly unrelated estimation framework which enables correcting for correlated error terms across models and testing for differences between models. Table 2 shows the results of the seemingly unrelated estimations for just gross earnings. The last column displays the results of postestimation tests for equality of coefficients across models. A significant result indicates that effects differ across models.

Both age and age-squared are statistically significant, and the coefficients indicate that "just"/"fair"/"appropriate" gross earnings increase to a peak and subsequently decline. The age at which just gross earnings peak is about 50 in the "just" and "appropriate" conditions and about 41 in the "fair" condition. As expected, men have higher just gross earnings, on average. While this is true for all three models, the effect is strongest in the "just" condition. Expressed in terms of the just gender multiplier routinely calculated in justice research (e.g., Jasso et al., 2019), which is defined as the exponential of the gender coefficient when women are coded 1 (or the exponential of the negative of the gender coefficient when men are coded 1) and interpreted as the ratio of female just earnings to male just earnings, the results in Table 2 indicate that on average, the just gender multiplier is substantially lower in the "just" condition-the gross earnings women regard as just are about $62 \%$ the gross earnings regarded as just by men-while in the "fair" and "appropriate" conditions the multiplier is about 69-70\%. The just base gross earnings, estimated for women aged 18 with lower-secondary education, are lowest in the "just" condition (903.25 Euro), followed by the "fair" condition (1037.95 Euro), and highest in the "appropriate" condition (1176.15 Euro). Higher education, as an indicator of higher perceived inputs, is also associated with higher expected "just," "fair," and "appropriate" returns. Compared to the reference category of completed lower secondary education, the higher the degree, the higher the expected returns. Overall, the effects of education are weakest in the "appropriate" condition.

Overall, these results indicate that the "just" condition produces just gross earnings that provide the smallest base amount, that peak later (by only a year relative to the "appropriate" condition but by 9 years relative to the "fair" condition), and that are substantially higher among men. While these findings generally suggest that the same set of reward-relevant characteristics are used in the just reward process across the three experimental conditions, the observed differences in microprinciples of 
justice across justice words warrant further research in order to pinpoint more precisely the effects of the justice words in the just reward process.

\section{The Just Reward Distribution and the Principles of Macrojustice}

The principles of macrojustice highlight the overall distribution and what it should look like (Sect. 2). To explore how principles of macrojustice guide respondents' ideas of one's own gross and net just earnings, we study characteristics of the just reward distributions by calculating measures of location (arithmetic mean and median) and measures of inequality (Atkinson, Gini, Theil Index, Theil MLD, CV). Table 3 reports these properties of the "just," "fair," and "appropriate" distributions for both gross and net earnings. As shown, the arithmetic mean and median are comparable across the three experimental groups for both gross and net earnings. However, Table 3 also shows that the "just" condition yields the largest average just gross earnings and the intermediate average just net earnings.

The general pattern of similarity is also observed for the five inequality measures. In tendency, the "fair" level of inequality is the highest across all measures of inequality (except for the Gini coefficient) for both gross and net earnings and the "appropriate" level of inequality of gross earnings is slightly lower compared to the "just" and "fair" inequality across all inequality measures.

Overall, analyses of the principles of macrojustice seem to suggest that properties of the just earnings distribution are similar across the three justice words. However, the observed differences in the principles of microjustice point to somewhat different conceptions of "just" earnings compared to "fair" and "appropriate" earnings. Building on this observation, the following section will scrutinize the role of justice words in the justice evaluation process.

\section{Justice Evaluation Process}

\section{Justice for Self: Expressed and Experienced Justice Evaluation}

Table 4 reports the average expressed and experienced justice evaluations of one's own gross and net earnings by justice word. Recall that the justice evaluation extends from negative numbers to positive numbers with extremes of underreward in the leftmost region, perfect justice at zero, and extremes of overreward in the rightmost region. Of the four justice evaluations shown-expressed and experienced, for gross and net earnings - three have the largest underreward, viz. the leftmost value, in the "just" condition, signaling that the just reward is highest in the "just" condition, consistent with the results above for the just reward.

Figure 2 provides a closer look at the distribution of response categories for the expressed justice evaluation of one's own gross earnings. As shown, although at first blush the proportions look somewhat similar across all justice words, some crossword patterns can be discerned. For example, not only did respondents in the "just" condition choose the scale midpoint (indicating perfect justice) least often but also respondents in the "fair" condition chose the scale midpoint more often. Moreover, 


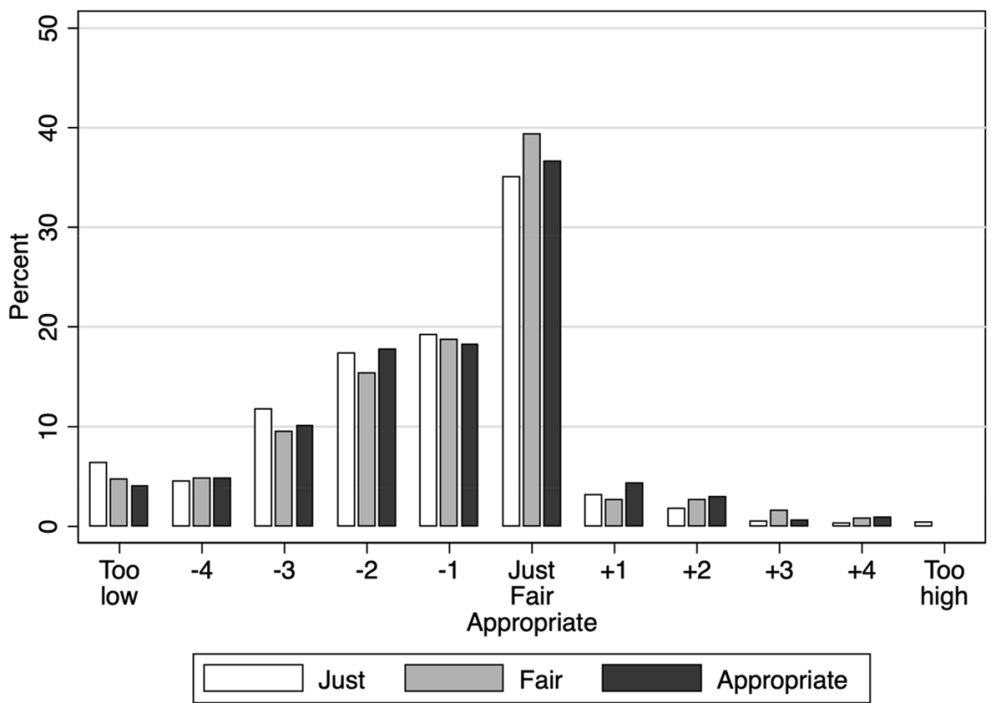

Fig. 2 Expressed Justice $J$ of One's Own Gross Earnings, by Justice Word. Data: GESIS Panel (Version 29.0; https://doi.org/10.4232/1.13244)

Table 2 Principles of Microjustice: Just Gross Earnings Equation, by Justice Word

\begin{tabular}{|c|c|c|c|c|c|c|c|}
\hline \multirow[b]{2}{*}{ Age } & \multicolumn{2}{|l|}{ M1: Just } & \multicolumn{2}{|l|}{ M2: Fair } & \multicolumn{3}{|c|}{ M3: Appropriate } \\
\hline & $0.099 * * *$ & $(0.017)$ & $0.081 * * *$ & $(0.015)$ & $0.097 * * *$ & $(0.017)$ & n.s \\
\hline $\mathrm{Age}^{2}$ & $-0.001 * * *$ & $(0.000)$ & $-0.001 * * *$ & $(0.000)$ & $-0.001 * * *$ & $(0.000)$ & n.s \\
\hline Male (1=yes) & $0.484 * * *$ & $(0.050)$ & $0.359 * * *$ & $(0.049)$ & $0.370 * * *$ & $(0.047)$ & $a^{+} b^{*}$ \\
\hline Lower secondary & Ref & & Ref & & Ref & & \\
\hline Intermediate & $0.276 * *$ & $(0.095)$ & 0.138 & $(0.088)$ & -0.093 & $(0.079)$ & $\mathrm{b}^{* *} \mathrm{c}^{+}$ \\
\hline Upper secondary & $0.286^{* *}$ & (0.104) & $0.237 *$ & $(0.100)$ & 0.012 & $(0.092)$ & $\mathrm{b}^{*} \mathrm{c}^{+}$ \\
\hline Lower tertiary & $0.409 * * *$ & $(0.097)$ & $0.537 * * *$ & $(0.085)$ & $0.244 * * *$ & $(0.078)$ & $\mathrm{c}^{*}$ \\
\hline Upper tertiary & $0.586 * * *$ & $(0.095)$ & $0.555 * * *$ & $(0.105)$ & $0.395 * * *$ & $(0.085)$ & n.s \\
\hline Constant & $5.042 * * *$ & $(0.399)$ & $5.505 * * *$ & $(0.341)$ & $5.342 * * *$ & $(0.382)$ & \\
\hline$R^{2}$ & 0.253 & & 0.231 & & 0.240 & & \\
\hline$N$ (single models) & 595 & & 610 & & 621 & & \\
\hline$N$ (overall) & 1826 & & & & & & \\
\hline
\end{tabular}

Data: GESIS Panel (Version 29.0; https://doi.org/10.4232/1.13244). Seemingly unrelated estimation, standard errors in parentheses. Log of just earnings regressed on age, age-squared, gender, and education. $\mathrm{R}^{2}$ values from separate OLS regression models. The last column displays results testing coefficients for equality across models: ${ }^{\text {a }}$ indicates a significant difference between the "just" (Model 1) and "fair" condition (Model 2), while ${ }^{b}$ indicates a significant difference between the "just" (Model 1) and "appropriate" condition (Model 3). " indicates a significant difference between the "fair" (Model 2) and "appropriate" condition (Model 3)

$+p<0.1, * p<0.05$, ** $p<0.01$, *** $p<0.001$ 
Table 3 Principles of Macrojustice: Two Measures of Location and Five Measures of Inequality, by Justice Word

\begin{tabular}{|c|c|c|c|c|c|c|c|c|}
\hline & \multicolumn{2}{|l|}{ Location } & \multicolumn{6}{|l|}{ Inequality } \\
\hline & Just mean & $\begin{array}{l}\text { Just } \\
\text { median }\end{array}$ & $\begin{array}{l}\text { Just Atkin- } \\
\text { son }\end{array}$ & Just Gini & $\begin{array}{l}\text { Just Theil } \\
\text { Index }\end{array}$ & $\begin{array}{l}\text { Just Theil } \\
\text { MLD }\end{array}$ & Just CV & $N$ \\
\hline \multicolumn{9}{|c|}{ Own gross earnings } \\
\hline Just & 3596.07 & 3200 & 0.176 & 0.311 & 0.160 & 0.193 & 0.572 & 643 \\
\hline Fair & 3568.18 & 3300 & 0.178 & 0.309 & 0.163 & 0.196 & 0.594 & 652 \\
\hline $\begin{array}{l}\text { Appropri- } \\
\text { ate }\end{array}$ & 3505.81 & 3200 & 0.167 & 0.299 & 0.148 & 0.182 & 0.546 & 657 \\
\hline \multicolumn{9}{|c|}{ Own net earnings } \\
\hline Just & 2368.02 & 2200 & 0.141 & 0.281 & 0.132 & 0.152 & 0.525 & 714 \\
\hline Fair & 2371.95 & 2200 & 0.144 & 0.278 & 0.132 & 0.155 & 0.526 & 703 \\
\hline $\begin{array}{l}\text { Appropri- } \\
\text { ate }\end{array}$ & 2304.31 & 2000 & 0.143 & 0.284 & 0.134 & 0.154 & 0.525 & 720 \\
\hline
\end{tabular}

Data: GESIS Panel (Version 29.0; https://doi.org/10.4232/1.13244). The sample on which the principles of macrojustice for own gross earnings were calculated was smaller compared to the sample for net earnings, because fewer respondents reported their just/fair/appropriate gross earnings compared to their just/ fair/appropriate net earnings

Table 4 Summary Characteristics of Expressed Justice Evaluation $J$ and Experienced Justice Evaluation $J^{*}$ of One's Own Earnings, by Justice Word

\begin{tabular}{|c|c|c|c|c|c|c|}
\hline & \multicolumn{3}{|c|}{$\begin{array}{l}\text { Expressed justice evalu- } \\
\text { ation } J\end{array}$} & \multicolumn{3}{|c|}{$\begin{array}{l}\text { Experienced justice } \\
\text { evaluation } J^{*}\end{array}$} \\
\hline & Mean & SD & $\mathrm{N}$ & Mean & SD & $N$ \\
\hline \multicolumn{7}{|c|}{ Own gross earnings } \\
\hline Just & -1.275 & 1.701 & 804 & -0.190 & 0.298 & 617 \\
\hline Fair & -1.051 & 1.701 & 788 & -0.161 & 0.263 & 626 \\
\hline Appropriate & -1.074 & 1.663 & 797 & -0.197 & 0.351 & 637 \\
\hline \multicolumn{7}{|c|}{ Own net earnings } \\
\hline Just & -1.253 & 1.716 & 829 & -0.207 & 0.307 & 690 \\
\hline Fair & -1.091 & 1.707 & 825 & -0.169 & 0.249 & 681 \\
\hline Appropriate & -1.060 & 1.636 & 813 & -0.196 & 0.335 & 701 \\
\hline
\end{tabular}

Data: GESIS Panel (Version 29.0; https://doi.org/10.4232/1.13244)

the most extreme underreward was reported more frequently in the "just" condition. One-way between-subject ANOVAs reveal that indeed the expressed justice evaluations of one's own gross earnings $(F(2,2366)=3.66, p=0.03)$ and net earnings $(F(2,2366)=3.42, p=0.03)$ differ by justice word. Post hoc pairwise comparisons using Student-Newman-Keuls (SNK) adjustment for multiple comparisons (e.g., Hilton \& Armstrong, 2006) indicate that expressed justice evaluations $J$ of both one's own gross and net earnings are significantly more positive (i.e., tending to the overreward region) in the "fair" and "appropriate" conditions compared to the "just" 
condition. However, the expressed justice evaluations do not differ significantly between the "fair" and "appropriate" conditions.

Analyses of the experienced justice evaluation $J^{*}$ show a similar pattern. The justice word does influence $J^{*}$ of gross earnings $(F(2,1847)=2.64, p=0.07)$ and net earnings $(F(2,1847)=3.28, p=0.04)$. Post hoc comparisons reveal that the experienced justice evaluations are more positive (i.e., tending to the overreward region) in the "fair" condition compared to the "just" condition, while $J^{*}$ does not differ between the "just" and "appropriate" conditions. Expressed justice evaluations in the "appropriate" condition are, however, significantly more negative compared to the "fair" condition, signaling larger just rewards.

\section{Justice for Others}

Turning to the justice evaluations of others' earnings at the top, middle, and bottom of the earnings distribution, we see a slightly different picture from what we observed for justice for self. Looking at the mean values displayed in Table 5, the expressed justice evaluations do not seem to differ across the three experimental conditions. A closer look at the response distributions for the justice evaluation of earnings at the top, middle, and bottom of the earnings distribution shows justice evaluations to be similar across conditions (see Figs. 3, 4, 5). For the justice evaluation of earnings at the top and the middle, the middle category was chosen most frequently in the "appropriate" condition.

However, one-way between-subject ANOVAs do not reveal a significant effect of justice words on either the justice evaluation of top earnings $(F(2,4110)=0.21$, $p=0.81)$, middle earnings $(F(2,4110)=1.33, p=0.26)$, or bottom earnings $(F$ $(2,4110)=0.56, p=0.57)$. While all justice evaluations of one's own earnings are affected by the justice word used in the survey question, the justice evaluations for others remain unaffected.

It has long been known that people experience the sense of justice about both self and others (Berger et al., 1972; Jasso, 1978), and questions and conjectures regularly arise about whether these two kinds of justice judgments operate differently and how they are combined (Jasso et al., 2016, 2019). If systematic differences in justice processes across self and other are couched in different words or use words differently, then the work reported in this paper opens the door to fuller and deeper understanding of justice. Note, however, that the justice evaluations of others' earnings were obtained not only from respondents who are in paid work themselves but also from respondents who were not working and did not receive any earnings. As the justice evaluation of earnings might be more relevant to individuals who are in paid work themselves, we ran separate ANOVAs with only those respondents receiving earnings. While the evaluation of top $(F(2,2158)=0.13, p=0.88)$ and middle earnings $(F(2,2158)=1.09, p=0.34)$ remained unaffected by the justice word used, among individuals in paid work, justice evaluations of the bottom earnings in Germany were significantly more positive (i.e., less underrewarded, tending toward the overreward region) in the "fair" condition compared to the "just" and "appropriate" conditions $(F(2,2158)=3.16, p=0.04)$. This tentatively suggests that persons in paid work provide more nuanced justice evaluations of the earnings of others, especially 


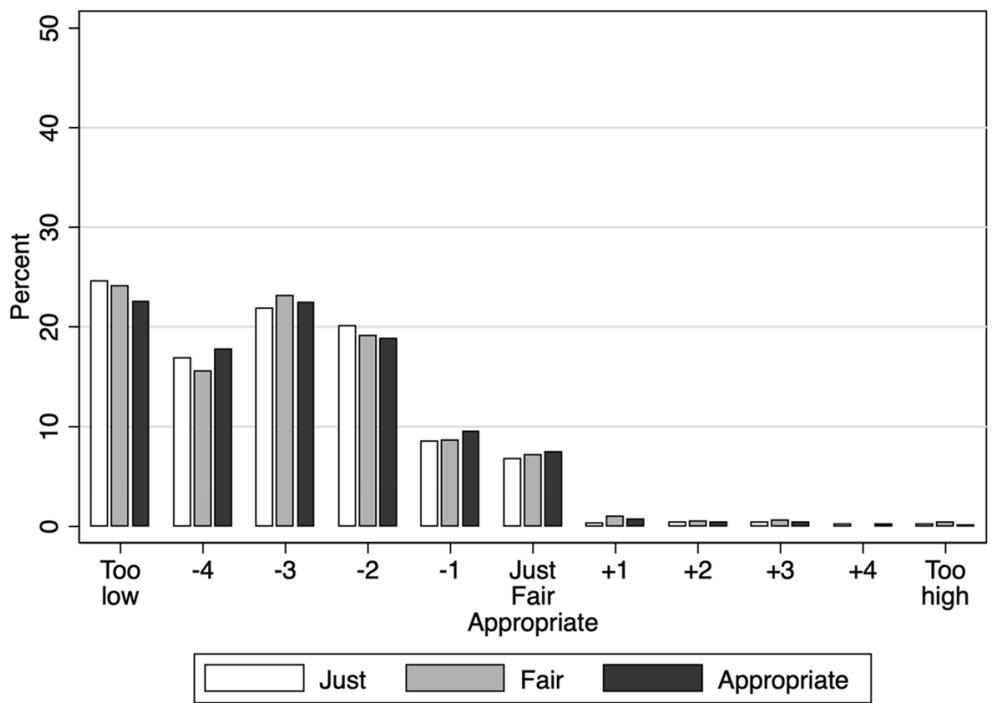

Fig. 3 Expressed Justice $J$ of Bottom Earnings, by Justice Word. Data: GESIS Panel (Version 29.0; https://doi.org/10.4232/1.13244)

Table 5 Summary

Characteristics of Expressed Justice Evaluation $J$ of Others' Earnings, by Justice Word

\begin{tabular}{lccc}
\hline & Mean & SD & $N$ \\
\hline \multicolumn{2}{l}{ Top earnings (Decile 10) } & & \\
Just & 0.922 & 1.802 & 1389 \\
Fair & 0.910 & 1.845 & 1408 \\
Appropriate & 0.869 & 1.678 & 1369 \\
Middle earnings (Decile 5) & & \\
Just & -2.220 & 1.656 & 1389 \\
Fair & -2.208 & 1.744 & 1421 \\
Appropriate & -2.131 & 1.640 & 1385 \\
Bottom earnings (Decile 1) & & \\
Just & -2.996 & 1.687 & 1409 \\
Fair & -2.925 & 1.752 & 1424 \\
Appropriate & -2.941 & 1.666 & 1385 \\
\hline
\end{tabular}

Data: GESIS Panel (Version 29.0; https://doi.org/10.4232/1.13244)

when evaluating very low earnings. In line with other research reports (Adriaans \& Liebig, 2018; Adriaans et al., 2019), respondents in Germany assess the most severe injustice for very low earnings. A particular concern for earnings at the bottom of the distribution may have contributed to the observation that only the evaluation of very low earnings was affected by the justice word used. 


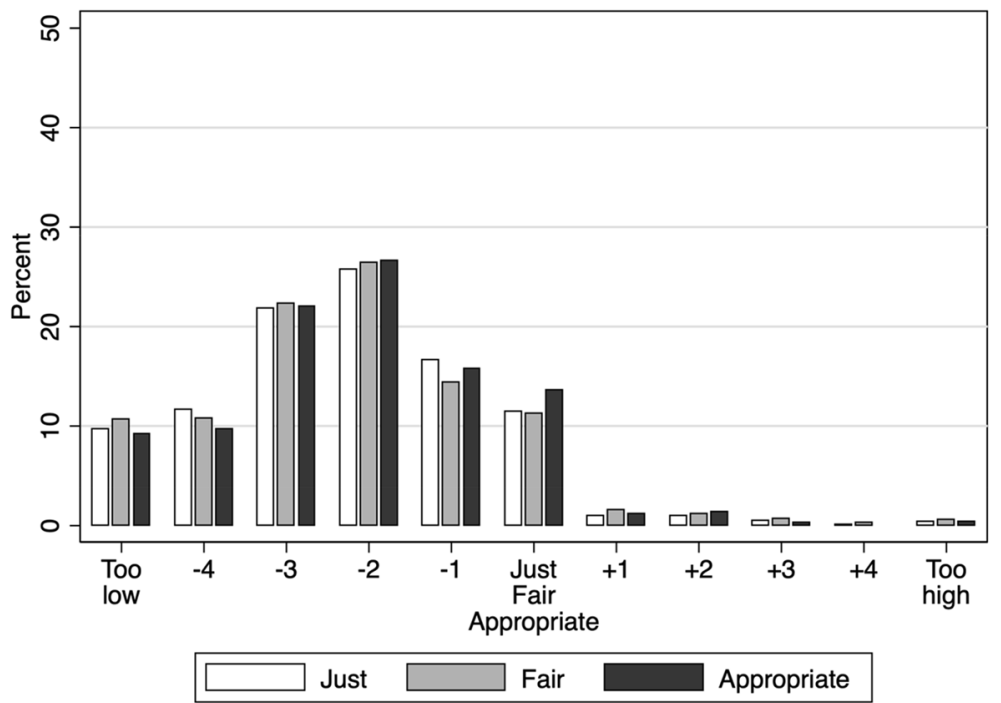

Fig. 4 Expressed Justice $J$ of Middle Earnings, by Justice Word. Data: GESIS Panel (Version 29.0; https://doi.org/10.4232/1.13244)

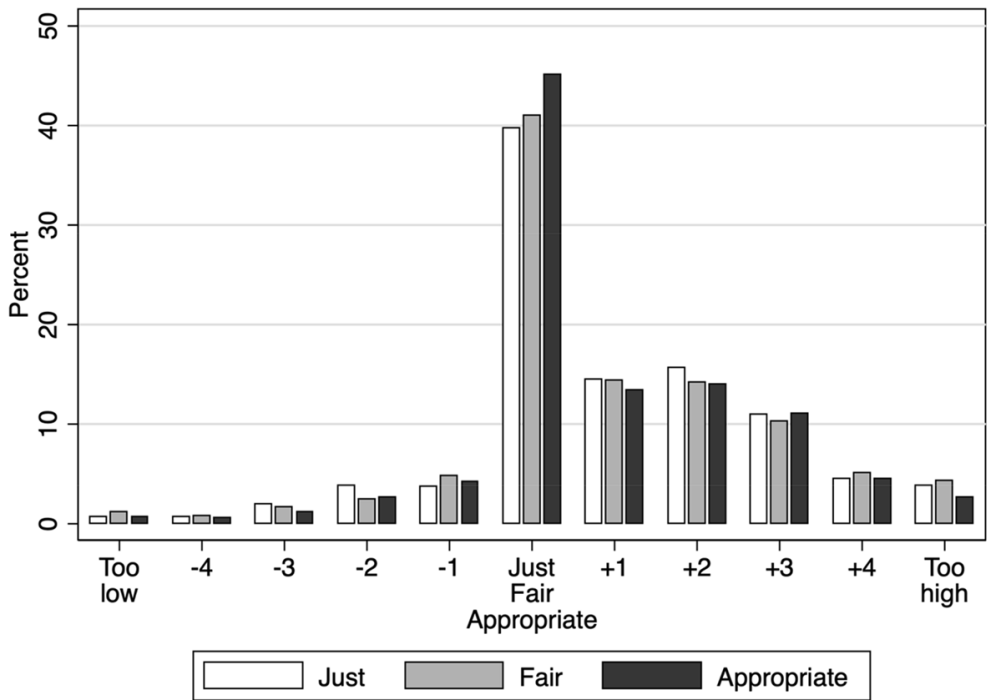

Fig. 5 Expressed Justice $J$ of Top Earnings, by Justice Word. Data: GESIS Panel (Version 29.0; https:// doi.org/10.4232/1.13244)

\section{Justice Consequences Process}

In the previous sections, we saw that both the just reward and the justice evaluation are affected by the justice word used. We now turn to the role of justice words in the 
justice consequences process. We address this question by estimating the effect of the justice evaluation of one's own earnings on putative consequences of injustice. By introducing the justice evaluation, the justice word (i.e., the experimental group), and their interaction into the models, we can detect whether the slope of the justice evaluation differs across justice stimuli. Significant interaction effects indicate that the effect of the justice evaluation differs between experimental groups pointing toward differences in the justice consequences process by justice word as well as in the underlying concepts of "justice," "fairness," and "appropriateness" among German respondents.

Tables 6 and 7 report the effect of the expressed and experienced justice evaluation, respectively, of one's own gross earnings on indicators of satisfaction, health, and trust. ${ }^{15}$ Inspecting main effects first, we see that, as the justice evaluation increases-from larger to smaller underreward or to overreward-respondents report higher levels of life satisfaction, job satisfaction, satisfaction with democracy, and health satisfaction. In a similar fashion, as the justice evaluation moves from larger to smaller underreward or from smaller overreward to larger overreward, respondents report higher levels of psychosocial health. Generalized trust is positively related to the expressed justice evaluation of gross earnings but not to the experienced justice evaluation of gross earnings.

Looking at the interaction effects of justice evaluation and justice word, we find no significant interaction effect for five out of six investigated justice consequences. The choice of justice word does not affect the association between the justice evaluation of gross earnings (both expressed $J$ and experienced $J^{*}$ ) and life satisfaction, job satisfaction, health satisfaction, satisfaction with democracy, and generalized trust. However, significant interaction effects in models M5a and M5b indicate that the associations between the justice evaluations of one's own gross earnings and the psychosocial health index differ by justice word. The decreasing effect of "unjustly underrewarded" earnings on the psychosocial health index is significantly stronger compared to the decreasing effect of "unfairly underrewarded" earnings. This interaction is only marginally significant for the expressed justice evaluation $J$ of one's own gross earnings, but highly significant for the experienced justice evaluation $J^{*}$ of one's own gross earnings.

Our findings indicate that for the majority of justice consequences studiednamely satisfaction and trust-the justice words do not affect the justice consequences process. However, we do find the effects of underreward in earnings on the psychosocial health index to differ in magnitude across the "just" and "fair" conditions. While underreward-regardless of whether it is "unjust," "unfair," or "inappropriate"-is generally associated with decreased levels of psychosocial health, the association is strongest in the "just" condition suggesting differences in the underlying construct. This warrants further research into how the effects of justice words

\footnotetext{
15 We ran the same analyses using the expressed justice evaluation $J$ and the experienced justice evaluation $J^{*}$ of one's own net earnings. Results are very much in line with the results for gross earnings. To conserve space, we therefore do not report these results; they are available from the authors upon request.
} 


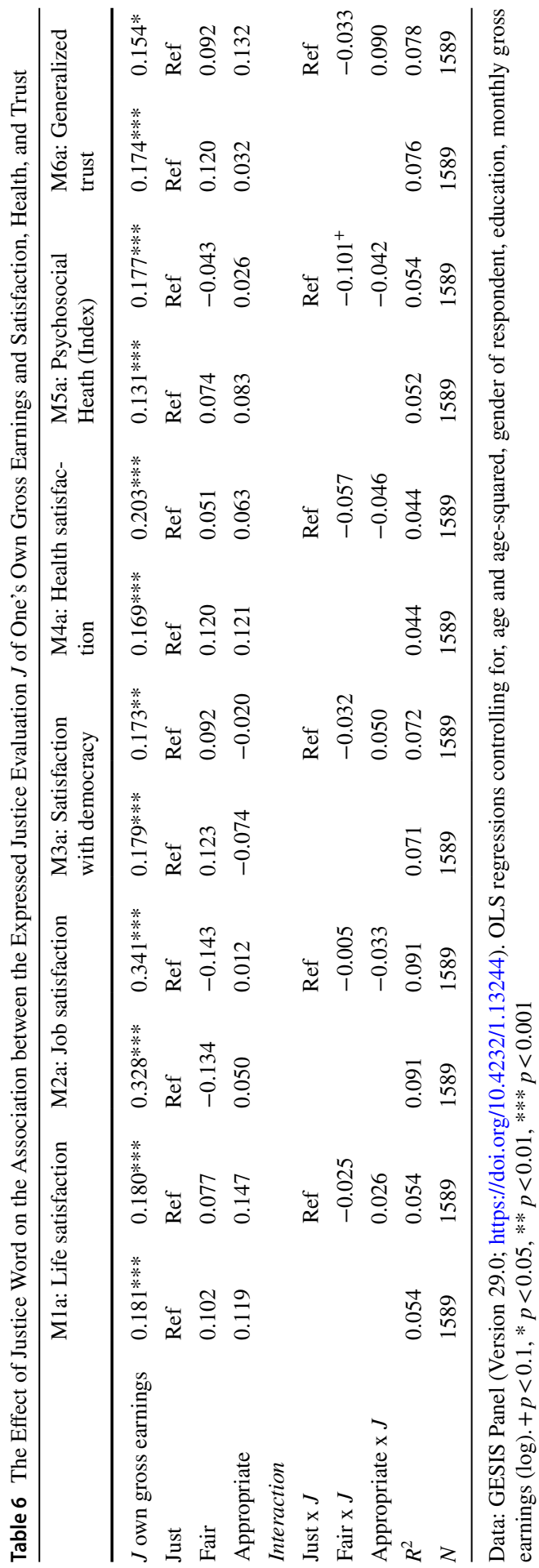




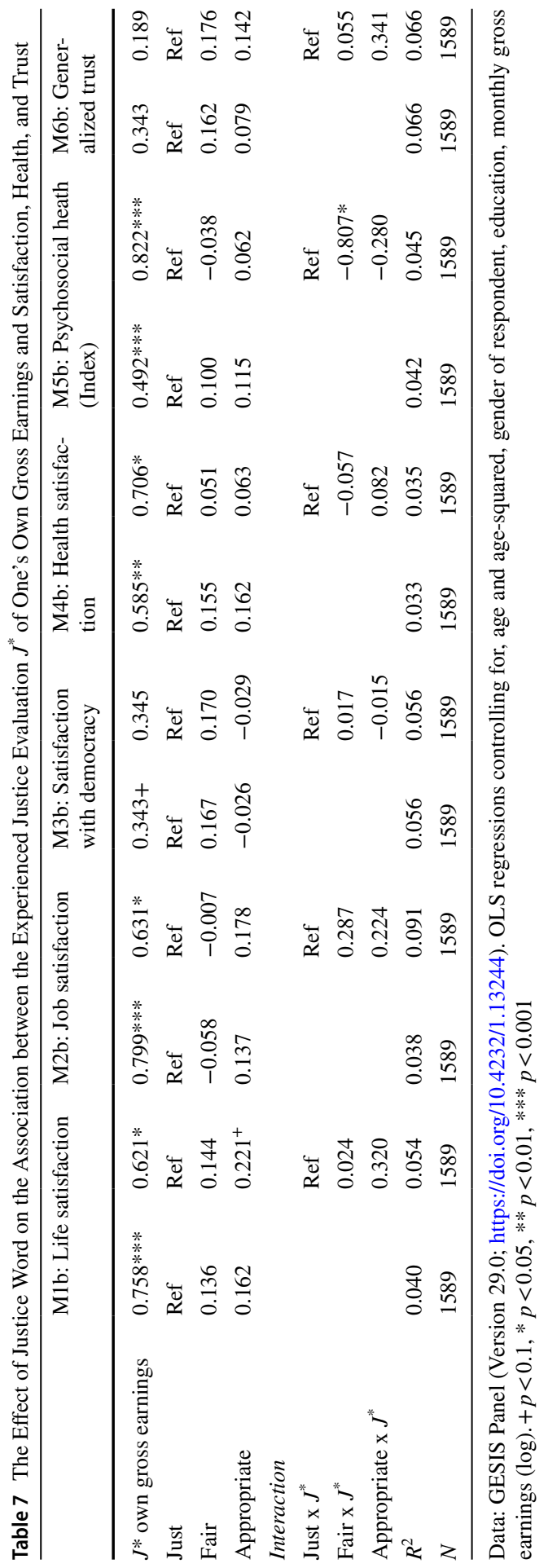


observed in the just reward process and the justice evaluation process translate into the justice consequences process.

\section{Discussion}

Justice is in the eye of the beholder. This guiding principle of empirical justice research signals the importance of asking ordinary people about their sense of justice. Notwithstanding theoretical calls to distinguish between the concepts of justice and fairness (e.g., Rawls, 1958) and insights from the survey research methods literature suggesting that seemingly synonymous changes to question wording can produce substantial variation in response behavior (e.g., Huber \& Paris, 2013; Schuman \& Presser, 1981), empirical justice researchers use justice words interchangeably in querying respondents and reporting their results. This study reports the results of an experiment that assessed the role that justice words-namely "just," "fair," and "appropriate" - play in eliciting justice evaluations of earnings. Drawing on this question wording experiment that was part of a mixed-mode panel study representative of the adult population in Germany, we investigated whether and how justice words affect three central processes identified in justice theory, namely (1) the just reward process, (2) the justice evaluation process, and (3) the justice consequences process.

Justice theory distinguishes between principles of microjustice and macrojustice that guide the just reward process. Scrutinizing both, we found that while conceptions of a just reward reflected in the microprinciples of justice seem to differ across the "just," "fair," and "appropriate" experimental conditions, the resulting distribution of just rewards was remarkably similar across them.

Turning to the justice evaluation process, we studied the effect of justice words on both the expressed and experienced justice evaluation of one's own earnings and the expressed justice evaluation of others' earnings. The question wording experiment revealed that indeed the justice evaluation of one's own earnings is affected by the justice word used. Respondents in the "just" condition assessed their own gross and net earnings less favorably compared to respondents in the "fair" and "appropriate" conditions. Generally, differences between justice words followed the same pattern for both expressed and experienced justice evaluations.

Respondents also evaluated the justice of the earnings of others. Surprisingly, these nonreflexive evaluations did not differ across experimental conditions for the whole sample. However, restricting analyses of nonreflexive evaluations to respondents who were in paid work revealed that their justice evaluations of bottom earnings in Germany differed by experimental conditions: It was significantly more positive (tending to overreward) in the "fair" condition than in the "just" and "appropriate" conditions. Justice evaluations of top and middle earnings, however, remained unaffected.

As noted above, it has long been known that people experience the sense of justice about both self and others (Berger et al., 1972; Jasso, 1978), and questions and conjectures regularly arise about whether these two kinds of justice judgments operate differently and how they are combined. Our findings with regard to the role of 
justice words in the justice evaluations for self and others suggest that justice evaluations, first, may be more nuanced when assessing one's own rewards than when assessing others' rewards, and this may be especially visible when contrasting across the three experimental conditions. This conclusion is further enhanced by our observation that principles of macrojustice - which keep the total distribution in mindseem to be more similar across conditions, while we observe more pronounced differences in microjustice between the manipulated justice words. Second, in our sample of German adults, those receiving earnings from work seem to provide more nuanced judgments of the earnings distribution compared to those who are not in paid work.

Overall, our analyses suggest that indeed there are differences in what people think is "just," "fair," and "appropriate" for self. Across multiple measures, justice evaluations in the "just" condition are deeper in the underreward territory, implying higher just rewards, followed by the "appropriate" and "fair" conditions. Indeed, "earnings justice" seems to be harder to achieve than "earnings fairness" or "earnings appropriateness," as we speculated based on the meaning of these justice words in the German language, with "just" referring to a formal sense of justice. To test the robustness of our findings, we excluded first- and second-generation immigrants from the analysis. As there is no information on language ability or mother tongue available in the data, this sample restriction came closest to eliminating differential language ability as a possible source of further differences in response behavior by justice word. Results for reflexive as well as nonreflexive evaluations also remained unchanged when controlling for level of education, as a proxy indicator for ability to differentiate between the three justice words.

If conceptions of "earnings justice," "earnings fairness," and "earnings appropriateness" indeed differ, the question remains whether they display distinctive associations with known justice consequences. Distinctive consequences would provide strong indication that the concepts underlying the three justice words differ fundamentally and may not be interchangeable for studying the justice consequences process identified in distributive justice theory. Our analyses into the justice consequences process, however, did not reveal differential justice consequences for generalized measures of satisfaction and trust across the three justice words, underlining that all three justice words capture evaluations that trigger the justice consequences process. Indeed, it does matter what people think and it matters for the assessment of "just," "fair," and "appropriate" alike. Nonetheless, the decreasing effect of underreward on psychosocial health is significantly stronger in the "just" word condition than in the "fair" word condition. This seems to be in line with the more general notion that "fairness" - in the German language-touches a less formal and more situational notion of "justice." A state of "injustice" therefore seems to be a more severe stressor compared to the same intensity of "unfairness."

In conclusion, our findings underscore that the choice of justice word affects the assessment of public opinion on matters of the justice of earnings. Although the observed differences in the just reward and justice evaluation are moderate in size, it is important to understand them as there seem to be systematic differences in what people think is just, fair, and appropriate, lending support to Rawls' insight and line of inquiry initiated more than 60 years ago. Follow-up research will therefore be 
useful to extend the investigation of dictionary definitions undertaken here and pinpoint more precisely these differences in the conceptions of "justice," "fairness," and "appropriateness." For example, directly asking ordinary people about the meaning of the words "just," "fair," and "appropriate" in open-format survey questions or qualitative approaches (e.g., cognitive interviewing) may shed new light on the observed patterns - guiding the measurement of public opinion on the sense of justice as well as advancing knowledge of justice matters more generally.

All three justice words tap the just reward process, the justice evaluation process, and the justice consequences process identified in justice theory. Nonetheless, the observed differences by justice word in all three processes central to distributive justice suggest some caution when comparing justice evaluations that use different justice words directly. In the German language context, researchers asking for the "fairness" of earnings will pick up evaluations that are systematically more positive (tending toward overreward thus signaling smaller just rewards) than researchers asking their respondents for the "justice" of earnings. Accordingly, researchers might consider using justice words consistently within a questionnaire and avoid presenting respondents with a mix of justice words. Such caution is especially warranted in cross-national studies because researchers are faced with the additional challenge of different languages and their specific justice words. Given crossnational research programs that collect data on just rewards and justice evaluations (e.g., ESS, 2019) and concerns about measurement equivalence, it remains critical to study the role of justice words in other language-country contexts as well.

Besides new experiments, there are three things that potentially would help advance the goal of understanding the role of language in justice research: First, build an online database, in which authors of published articles can list the publication details and indicate the language-country research context as well as the specific justice words used with respondents. Second, issue a call for new research on unanalyzed data that varies justice words. Third, in each future published article, use the final keyword to indicate the language-country context (e.g., German-Germany, German-Germany/Austria, English-Canada/USA, and so on).

For now, with respect to one's own earnings in Germany, the "just" reward is larger than the "fair" reward, the "justice" evaluation tends more to underreward than the "fairness" evaluation, and "justice" shows a stronger association with psychosocial health than "fairness," while associations with satisfaction and trust do not differ by justice word. Future research will discern more clearly the differences between Rawlsian justice and Rawlsian fairness - and other justice words-across rewards, self and others, and language-country contexts.

\section{Appendix}

See Fig. 6, Tables 8, 9, and 10. 


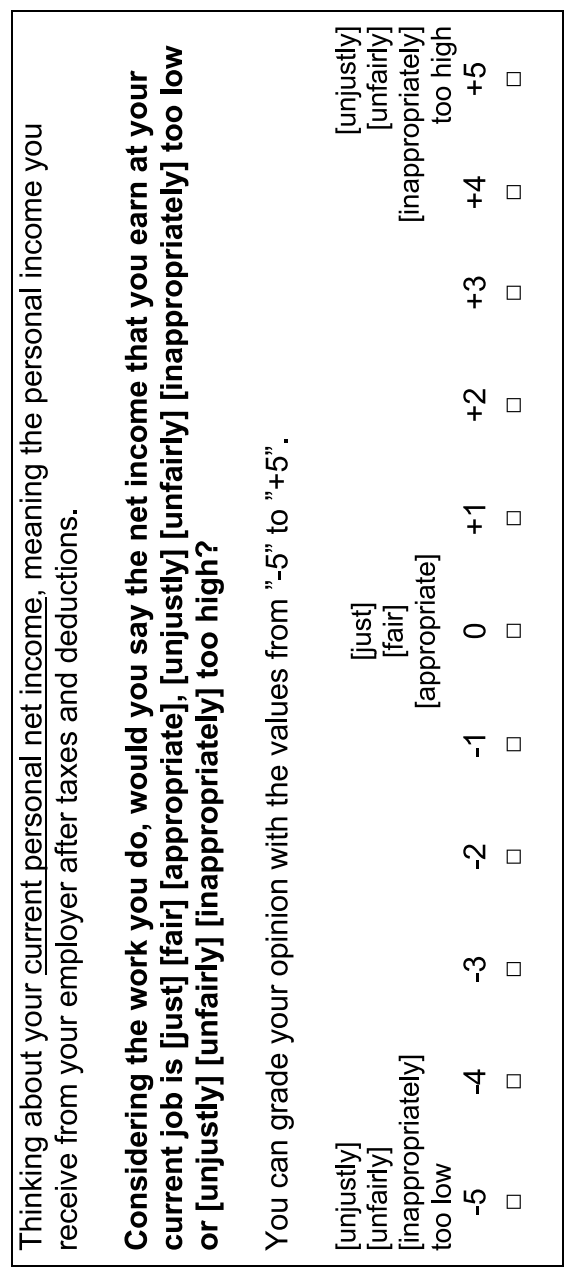

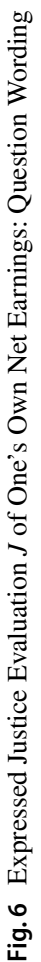


Table 8 Question Wording-Justice Evaluation of One's Own Earnings

German English translation

Expressed Justice Evaluation J of Net Earnings

Bitte denken Sie an Ihr gegenwärtiges persönliches NettoEinkommen, also das Einkommen das Sie nach Abzug von Steuern und Abgaben von Ihrem Arbeitgeber erhalten

Würden Sie sagen, dass es in Bezug auf Ihre Tätigkeit [gerecht] [fair] [angemessen], [ungerechterweise] [unfairerweise] [unangemessenerweise] zu niedrig oder [ungerechterweise] [unfairerweise] [unangemessenerweise] zu hoch ist?

Mit den Werten zwischen "-5" und " +5 " können Sie Ihre Meinung abstufen

[ungerechterweise] [unfairerweise] [unangemessenerweise] zu niedrig $(-5)$

[Gerecht] [Fair] [Angemessen] (0)

[ungerechterweise] [unfairerweise] [unangemessenerweise] $\mathrm{zu}$ hoch $(+5)$

\section{Just Net Earnings}

Was wäre in Ihren Augen ein [gerechtes] [faires] [angemessenes] monatliches Netto-Einkommen für Sie?

\section{Actual Net Earnings}

Wie hoch ist Ihr eigenes monatliches Netto-Einkommen aus Ihrer Erwerbstätigkeit?

Gemeint ist der Betrag, den Sie nach Abzug von Steuern und Abgaben von Ihrem Arbeitgeber erhalten. Falls Sie selbständig sind, geben Sie bitte den Betrag an, den Sie durchschnittlich im Monat verdienen

\section{Expressed Justice Evaluation J of Gross Earnings}

Bitte denken Sie jetzt an Ihr gegenwärtiges persönliches Brutto-Einkommen, also das Einkommen das Sie vor Abzug von Steuern und Abgaben von Ihrem Arbeitgeber erhalten

Würden Sie sagen, dass es in Bezug auf Ihre Tätigkeit [gerecht] [fair] [angemessen], [ungerechterweise] [unfairerweise] [unangemessenerweise] zu niedrig oder [ungerechterweise] [unfairerweise] [unangemessenerweise] $\mathrm{zu}$ hoch ist?

Mit den Werten zwischen "-5" und " +5 " können Sie Ihre Meinung abstufen

[ungerechterweise] [unfairerweise] [unangemessenerweise] zu niedrig $(-5)$

[Gerecht] [Fair] [Angemessen] (0)

[ungerechterweise] [unfairerweise] [unangemessenerweise] $\mathrm{zu}$ hoch $(+5)$

\section{Just Gross Earnings}

Was wäre in Ihren Augen ein [gerechtes] [faires] [angemessenes] monatliches Brutto-Einkommen für Sie?

\section{Actual Gross Earnings}

Wie hoch ist Ihr eigenes monatliches Brutto-Einkommen aus Ihrer Erwerbstätigkeit?

Gemeint ist der Betrag, den Sie vor Abzug von Steuern und Abgaben von Ihrem Arbeitgeber erhalten. Falls Sie selbständig sind, geben Sie bitte den Betrag an, den Sie durchschnittlich im Monat verdienen
Thinking about your current personal net income, meaning the personal income you receive from your employer after taxes and deductions

Considering the work you do, would you say the net income that you earn at your current job is [just] [fair] [appropriate], [unjustly] [unfairly] [inappropriately] too low or [unjustly] [unfairly] [inappropriately] too high?

You can grade your opinion with the values from " $-5 "$ to "+5"

[unjustly] [unfairly] [inappropriately] too low (-5) [just] [fair] [appropriate] (0)

[unjustly] [unfairly] [inappropriately] too high $(+5)$

What would be a [just] [fair] [appropriate] monthly net income in your opinion?

What is your monthly net income from work?

Meaning the amount you receive from your employer after taxes and deductions. If you are self-employed, please state your average monthly earnings

Thinking about your current personal gross income, meaning the personal income you receive from your employer before taxes and deductions

Considering the work you do, would you say the gross income that you earn at your current job is [just] [fair] [appropriate], [unjustly] [unfairly] [inappropriately] too low or [unjustly] [unfairly] [inappropriately] too high?

You can grade your opinion with the values from " $-5 "$ to " +5 "

[unjustly] [unfairly] [inappropriately] too low (-5) [just] [fair] [appropriate] (0)

[unjustly] [unfairly] [inappropriately] too high $(+5)$

What would be a [just] [fair] [appropriate] monthly gross income in your opinion?

What is your monthly gross income from work?

Meaning the amount you receive from your employer before taxes and deductions. If you are self-employed, please state your average monthly earnings 
Table 9 Question Wording_Justice Evaluation of Others' Earnings

German English translation

Expressed Justice Evaluation J of Top Gross Earnings

Wenn Sie einmal daran denken, was andere hier in Deutschland vor Abzug von Steuern und Abgaben verdienen

Wie [gerecht] [fair] [angemessen] ist das Brutto-Einkommen derjenigen, die in Berufen mit hohen Einkommen tätig sind, wie zum Beispiel Ärzte, Ingenieure oder Unternehmensberater?

Würden Sie sagen, dass diese Einkommen [gerecht] [fair] [angemessen], [ungerechterweise] [unfairerweise] [unangemessenerweise] zu niedrig oder [ungerechterweise] [unfairerweise] [unangemessenerweise] zu hoch ist?

Mit den Werten zwischen " -5 ” und “+5” können Sie Ihre Meinung abstufen

[ungerechterweise] [unfairerweise] [unangemessenerweise] zu niedrig $(-5)$

[Gerecht] [Fair] [Angemessen] (0)

[ungerechterweise] [unfairerweise] [unangemessenerweise] zu hoch $(+5)$

Expressed Justice Evaluation J of Middle Gross Earnings

Und wie [gerecht] [fair] [angemessen] ist aus Ihrer Sicht das Brutto-Einkommen derjenigen, die in Deutschland in Berufen mit mittleren Einkommen tätig sind, wie zum Beispiel Krankenschwestern bzw. Krankenpfleger, Buchhalter oder Elektriker?

Würden Sie sagen, dass diese Einkommen [gerecht] [fair] [angemessen], [ungerechterweise] [unfairerweise] [unangemessenerweise] zu niedrig oder [ungerechterweise] [unfairerweise] [unangemessenerweise] zu hoch ist?

Mit den Werten zwischen " -5 ” und “ +5 ” können Sie Ihre Meinung abstufen

[ungerechterweise] [unfairerweise] [unangemessenerweise] zu niedrig $(-5)$

[Gerecht] [Fair] [Angemessen] (0)

[ungerechterweise] [unfairerweise] [unangemessenerweise] zu hoch $(+5)$

Expressed Justice Evaluation J of Bottom Gross Earnings

Und wie [gerecht] [fair] [angemessen] ist aus Ihrer Sicht das Brutto-Einkommen derjenigen, die in Deutschland in Berufen mit niedrigen Einkommen tätig sind, wie zum Beispiel Reinigungskräfte, Friseure oder Paketboten?

Würden Sie sagen, dass diese Einkommen [gerecht] [fair] [angemessen], [ungerechterweise] [unfairerweise] [unangemessenerweise] zu niedrig oder [ungerechterweise] [unfairerweise] [unangemessenerweise] zu hoch ist?

Mit den Werten zwischen " -5 " und " +5 " können Sie Ihre Meinung abstufen

[ungerechterweise] [unfairerweise] [unangemessenerweise] zu niedrig $(-5)$

[Gerecht] [Fair] [Angemessen] (0)

[ungerechterweise] [unfairerweise] [unangemessenerweise] zu hoch $(+5)$
Thinking about what other people in Germany earn before taxed and deductions

How [just] [fair] [appropriate] is the gross income of those working in occupations with high incomes, e.g. doctors, engineers and business consultants? Would you say these incomes are [just] [fair] [appropriate], [unjustly] [unfairly] [inappropriately] too low or [unjustly] [unfairly] [inappropriately] too high?

You can grade your opinion with the values from " -5 " to " +5 "

[unjustly] [unfairly] [inappropriately] too low (-5) [just] [fair] [appropriate] (0)

[unjustly] [unfairly] [inappropriately] too high (+5)

And how [just] [fair] [appropriate] is the gross income of those working in occupations with medium incomes, e.g., nurses, accountants and electricians? Would you say these incomes are [just] [fair] [appropriate], [unjustly] [unfairly] [inappropriately] too low or [unjustly] [unfairly] [inappropriately] too high?

You can grade your opinion with the values from " -5 " to " +5 "

[unjustly] [unfairly] [inappropriately] too low (-5) [just] [fair] [appropriate] (0) [unjustly] [unfairly] [inappropriately] too high (+5)

And how [just] [fair] [appropriate] is the gross income of those working in occupations with low incomes, e.g., cleaning staff, hair dressers and parcel carriers? Would you say these incomes are [just] [fair] [appropriate], [unjustly] [unfairly] [inappropriately] too low or [unjustly] [unfairly] [inappropriately] too high?

You can grade your opinion with the values from " -5 " to " +5 "

[unjustly] [unfairly] [inappropriately] too low (-5) [just] [fair] [appropriate] (0) [unjustly] [unfairly] [inappropriately] too high $(+5)$ 
Table 10 Summary Characteristics of Control Variables and Justice Consequences, by Justice Word

\begin{tabular}{|c|c|c|c|c|c|c|}
\hline & \multicolumn{2}{|l|}{ Just } & \multicolumn{2}{|l|}{ Fair } & \multicolumn{2}{|c|}{ Appropriate } \\
\hline & Mean & $\mathrm{SD}$ & Mean & SD & Mean & $\mathrm{SD}$ \\
\hline \multicolumn{7}{|l|}{ Control Variables } \\
\hline Age & 51.865 & 14.542 & 51.451 & 15.111 & 51.477 & 14.605 \\
\hline Male ( $1=$ yes $)$ & 0.471 & - & 0.503 & - & 0.493 & - \\
\hline \multicolumn{7}{|l|}{ Education } \\
\hline Lower secondary & 0.142 & - & 0.157 & - & 0.147 & - \\
\hline Intermediate & 0.254 & - & 0.227 & - & 0.242 & - \\
\hline Upper secondary & 0.112 & - & 0.127 & - & 0.122 & - \\
\hline Lower tertiary & 0.288 & - & 0.289 & - & 0.287 & - \\
\hline Upper tertiary & 0.203 & - & 0.199 & - & 0.203 & - \\
\hline $\begin{array}{l}\text { Gross monthly } \\
\text { earnings }\end{array}$ & 3111.634 & 1982.490 & 3139.806 & 2125.272 & 2996.412 & 1845.944 \\
\hline \multicolumn{7}{|l|}{ Justice Consequences } \\
\hline Life satisfaction & 7.059 & 1.918 & 7.032 & 1.943 & 7.133 & 1.875 \\
\hline Job satisfaction & 7.019 & 2.201 & 6.886 & 2.213 & 7.016 & 2.248 \\
\hline Satisfaction with democracy & 5.856 & 2.341 & 5.865 & 2.412 & 5.896 & 2.424 \\
\hline Health satisfaction & 6.552 & 2.330 & 6.562 & 2.352 & 6.665 & 2.250 \\
\hline Psychosocial health (index) & 6.233 & 1.758 & 6.301 & 1.728 & 6.319 & 1.727 \\
\hline Generalized trust & 4.969 & 2.689 & 4.942 & 2.730 & 5.049 & 2.698 \\
\hline
\end{tabular}

Data: GESIS Panel (Version 29.0; https://doi.org/10.4232/1.13244)

Acknowledgements Earlier versions of portions of this article were presented at the 8th Conference of the European Survey Research Association (ESRA), Zagreb, Croatia, July 2019; at the annual Group Processes Conference, New York, NY, August 2019; at the International Network of Analytical Sociology (INAS) 13th Annual Conference, Online, May 2021; and at the 18th International Society for Justice Research (ISJR) conference, Online, July 2021. We thank conference participants, the anonymous reviewers, the Editorial Team, and the Editor for their valuable comments and suggestions.

Funding Open Access funding enabled and organized by Projekt DEAL. Adriaans and Liebig acknowledge funding from the German Research Foundation (DFG) as part of the project "Structural Conditions of Justice Attitudes Over the Life-Span” (grant number: LI 987/7-1).

Availability of Data and Material The analyses draw on the extended edition of the GESIS Panel data (Version 29.0; https://doi.org/10.4232/1.13244). The extended edition of the GESIS Panel data is available in the Secure Data Center at the GESIS Data Archive for Social Sciences in Cologne. In order to gain access to the data, researchers are required to sign a special data usage contract and to work in an individually setup, secure, virtual work environment at GESIS in Cologne.

Code Availability All analyses were performed using Stata 15. Code is available from the authors upon request.

\section{Declarations}

Conflict of interest The authors declare that they have no conflict of interest. 
Ethical Approval All procedures performed in studies involving human participants were in accordance with the ethical standards of the institutional and/or national research committee and with the 1964 Declaration of Helsinki and its later amendments or comparable ethical standards.

Informed Consent Informed consent was obtained from all individual participants included in the study.

Open Access This article is licensed under a Creative Commons Attribution 4.0 International License, which permits use, sharing, adaptation, distribution and reproduction in any medium or format, as long as you give appropriate credit to the original author(s) and the source, provide a link to the Creative Commons licence, and indicate if changes were made. The images or other third party material in this article are included in the article's Creative Commons licence, unless indicated otherwise in a credit line to the material. If material is not included in the article's Creative Commons licence and your intended use is not permitted by statutory regulation or exceeds the permitted use, you will need to obtain permission directly from the copyright holder. To view a copy of this licence, visit http://creativecommons.org/licen ses/by/4.0\%.

\section{References}

Adams, J. S. (1963). Toward an understanding of inequity. Journal of Abnormal and Social Psychology, $67(5), 422-436$.

Adriaans, J., \& Liebig, S. (2018). Inequality of earnings in Germany generally accepted but low incomes considered unfair. DIW Weekly Report, 8(37), 347-352.

Adriaans, J., Eisnecker, P., \& Liebig, S. (2019). A comparison of earnings justice throughout Europe: widespread approval in Germany for income distribution according to need and equity. DIW Weekly Report, 9(44/45), 397-404.

Alesina, A., \& La Ferrara, E. (2002). Who trusts others? Journal of Public Economics, 85(2), 207-234.

Auspurg, K., Hinz, T., \& Sauer, C. (2017). Why should women get less? Evidence on the gender pay gap from multifactorial survey experiments. American Sociological Review, 82(1), 179-210.

Berger, J., Zelditch, M., Jr., Anderson, B., \& Cohen, B. P. (1972). Structural Aspects of Distributive Justice: A Status-Value Formulation. In J. Berger, M. Zelditch, \& B. Anderson (Eds.), Sociological Theories in Progress (Vol. 2, pp. 119-246). Houghton Mifflin.

Bosnjak, M., Dannwolf, T., Enderle, T., Schaurer, I., Struminskaya, B., Tanner, A., \& Weyandt, K. W. (2017). Establishing an open probability-based mixed-mode panel of the general population in Germany. Social Science Computer Review, 36(1), 103-115. https://doi.org/10.1177/0894439317 697949

Brickman, P., Folger, R., Goode, E., \& Schul, Y. (1981). Micro and macro justice. In M. J. Lerner \& S. C. Lerner (Eds.), The Justice Motive in Social Behavior (pp. 173-202). Plenum.

Colquitt, J. A., \& Rodell, J. B. (2015). Measuring Justice and Fairness. In R. Cropanzano \& M. Ambrose (Eds.), The Oxford Handbook of Justice in Work Organizations (pp. 187-202). The Oxford University Press.

Colquitt, J. A., \& Shaw, J. C. (2005). How Should Organizational Justice Be Measured? In J. A. Colquitt \& J. Greenberg (Eds.), Handbook of Organizational Justice (pp. 113-152). Lawrence Erlbaum Associates.

Cugueró-Escofet, N., \& Rosanas, J. M. (2013). The just design and use of management control systems as requirements for goal congruence. Management Accounting Research, 24(1), 23-40.

Deutsch, M. (1975). Equity, equality, and need: What determines which value will be used as the basis of distributive justice? Journal of Social Issues, 31(3), 137-149.

Duden. (2018). Das Bedeutungswörterbuch (5 ed. Vol. 10). Berlin: Duden Verlag.

Earley, P. C., \& Lind, E. A. (1987). Procedural justice and participation in task selection: The role of control in mediating justice judgments. Journal of Personality and Social Psychology, 52(6), 11481160. https://doi.org/10.1037/0022-3514.52.6.1148

ESS. (2019). ESS Round 9 Module on Justice and Fairness - Question Design Final Module in Template. City University.

Fortin, M., \& Fellenz, M. R. (2008). Hypocrisies of fairness: Towards a more reflexive ethical base in Organizational Justice Research and Practice. Journal of Business Ethics, 78(3), 415-433. 
Friedman, M. (1977). Fair versus Free. Newsweek, 4 July 1977, p. 70. Originally delivered as a commencement address at Virginia Polytechnic Institute and State University, 28 May 1977.

GESIS (2021). GESIS Panel - Extended Edition. GESIS Datenarchiv, Köln. ZA5664 Datenfile Version 29.0.0.https://doi.org/10.4232/1.13244.

Goldman, B., \& Cropanzano, R. (2015). "Justice" and "Fairness" are not the same thing. Journal of Organizational Behavior, 36(2), 313-318.

Hegtvedt, K., Johnson, C., \& Watson, L. (2016). Social Dynamics of Legitimacy and Justice. In C. Sabbagh \& M. Schmitt (Eds.), Handbook of Social Justice Theory and Research (pp. 425-444). Springer.

Hegtvedt, K. (2006). Justice Frameworks. In P. J. Burke (Ed.), Contemporary Social Psychological Theories. Standford: Standford University Press.

Hilton, A., \& Armstrong, R. (2006). Statnote 6: Post-hoc ANOVA tests. Micorbiologist, 2006, 34-36.

Huber, G. A., \& Paris, C. (2013). Assessing the programmatic equivalence assumtion in question wording experiments. Public Opinion Quarterly, 77(1), 385-397.

Hülle, S., Liebig, S., \& May, M. J. (2018). Measuring attitudes toward distributive justice: The basic social justice orientations scale. Social Indicators Research, 136, 663-692.

Jasso, G. (1978). On the justice of earnings: A new specification of the justice evaluation function. American Journal of Sociology, 83(6), 1398-1419.

Jasso, G. (2007). Studying Justice: Measurement, Estimation, and Analysis of the Actual Reward and the Just Reward. In K. Törnblom \& R. Vermunt (Eds.), Distributive and Procedural Justice: Research and Social Applications (pp. 225-253). Ashgate Publishing Company.

Jasso, G. (2018). What can you and I do to reduce income inequality? The Journal of Mathematical Sociology, 42(4), 186-204.

Jasso, G., \& Meyerson Milgrom, E. M. (2008). Distributive justice and CEO compensation. Acta Sociologica, 51(2), 123-143.

Jasso, G., \& Wegener, B. (1997). Methods for empirical justice analysis: Part 1, Framework, models, and quantities. Social Justice Research, 10(4), 393-430.

Jasso, G., \& Wegener, B. (1999). Gender and country differences in the sense of justice: Justice evaluation, gender earnings gap, and earnings functions in thirteen Countries. International Journal of Comparative Sociology, 40(1), 94-116.

Jasso, G., Törnblom, K., \& Sabbagh, C. (2016). Distributive Justice. In C. Sabbagh \& M. Schmitt (Eds.), Handbook of Social Justice Theory and Research (pp. 201-218). Springer.

Jasso, G., Shelly, R., \& Webster, M., Jr. (2019). How impartial are the observers of justice theory? Social Science Research, 79, 226-246.

Kempcke, G. (2000). Wörterbuch Deutsch als Fremdsprache. Walter de Gruyter.

Liebig, S. (2001). Lessons from Philosophy? Interdisciplinary justice research and two classes of justice judgments. Social Justice Research, 14(3), 265-287.

Liebig, S., \& Sauer, C. (2016). The Sociology of Justice. In C. Sabbagh \& M. Schmitt (Eds.), Handbook of Social Justice Theory and Research (pp. 37-59). Springer.

Lundmark, S., Gilljam, M., \& Dahlberg, S. (2016). Measuring generalized trust. An examination of question wording and the number of scale points. Public Opinion Quarterly, 80(1), 26-43.

Mincer, J. A. (1974). Schooling, Experience and Earnings. National Bureau of Economic Research.

Raphael, D. D. (2001). Concepts of Justice. Oxford Clarendon.

Rasinski, K. A. (1989). The effect of question wording on public support for Government spending. Public Opinion Quarterly, 53, 388-394.

Rawls, J. (1958). Justice as fairness. The Philosophical Review, 67, 164-194.

Rawls, J. (1971). A Theory of Justice. Cambridge.

Ridgeway, C. (1991). The social construction of status value: Gender and other nominal characteristics. Social Forces, 70(2), 367-386.

Sabbagh, C., \& Schmitt, M. (2016). Handbook of Social Justice Theory And Research. Springer.

Sauer, C., \& Valet, P. (2013). Less is sometimes more: Consequences of overpayment on job satisfaction and Absenteeism. Social Justice Research, 26(2), 132-150.

Sauer, C., Valet, P., \& Liebig, S. (2016). Welche Lohnungleichheiten sind gerecht? Kölner Zeitschrift Für Soziologie Und Sozialpsychologie, 68, 619-645.

Schuman, H., \& Presser, S. (1981). Questions And Answers in Attitude Surveys. Academic Press.

Schunck, R., Sauer, C., \& Valet, P. (2015). Unfair pay and health: The effects of perceived injustice of earnings on physical health. European Sociological Review, 31(6), 655-666. https://doi.org/10. 1093/esr/jcv065 
Seebold, E. (2002). Kluge. Etymologisches Wörterbuch der deutschen Sprache (24th ed.). Walter de Gruyter.

Sen, A. (2009). The Idea of Justice. Harvard University Press.

Singer, E., \& Couper, M. P. (2014). The effect of question wording on attitudes toward prenatal testing and abortion. Public Opinion Quarterly, 78(3), 751-760.

Smith, T. W. (1987). That which we call welfare by any other name would smell sweeter. Public Opinion Quarterly, 51, 75-83.

Törnblom, K., \& Kazemi, A. (2015). Distributive Justice: Revisiting Past Statements and Reflecting Future Prospects. In R. S. Cropranzano \& M. L. Ambrose (Eds.), The Oxford Handbook of Justice in the Workplace (pp. 15-50). Oxford University Press.

Turiel, E. (1983). The Development of Social Knowledge: Morality and Convention. Cambridge University Press.

Valet, P. (2018). Social structure and the paradox of the contended female worker: How occupational gender segregation biases justice perceptions of wages. Work and Occupations, 45(2), 168-193.

Walster, E., Berscheid, E., \& Walster, G. W. (1973). New directions in equity research. Journal of Personality and Social Psychology, 25(2), 151-176.

Weinhardt, M., \& Richter, D. (2014). SF-12-S Short Form-12 Health Survey-SOEP. In C. J. Kemper, E. Brähler, \& M. Zenger (Eds.), Psychologische und sozialwissenschaftliche Kurzskalen standardisierter Erhebungsinstrumente für Wissenschaft und Praxis (pp. 275-278). Medizinisch Wissenschaftliche Verlagsgesellschaft.

Wolfram, H. (1990). Die Goten und ihre Geschichte. C. H. Beck.

Publisher's Note Springer Nature remains neutral with regard to jurisdictional claims in published maps and institutional affiliations.

\title{
Authors and Affiliations
}

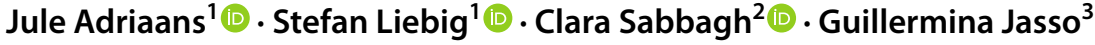 \\ Stefan Liebig \\ sliebig@diw.de \\ Clara Sabbagh \\ csabbagh@edu.haifa.ac.il \\ Guillermina Jasso \\ gj1@ nyu.edu \\ 1 Socio-Economic Panel Study, German Institute for Economic Research (DIW Berlin), Berlin, \\ Germany \\ 2 Department of Leadership and Policy in Education, University of Haifa, Haifa, Israel \\ 3 Department of Sociology, New York University, New York City, NY, USA
}

